\title{
Określenia chrześcijańskich duchownych Kościołów innych niż katolicki w polszczyźnie XVI wieku
}

\author{
The Names of Christian Clergymen from Churches Other than \\ Catholic in the Polish Language of the 16th Century
}

\author{
Jolanta Migdał \\ Wydział Filologii Polskiej i Klasycznej, Uniwersytet im. Adama Mickiewicza w Poznaniu, \\ ul. Fredry 10, 61-701 Poznań, Polska; \\ e-mail: jolamig@amu.edu.pl
}

\begin{abstract}
The article discusses 21 designations for Christian clergymen from Churches other than Catholic from the 16th century. They are general names of Orthodox and Protestant clergymen as well as the names of high-ranking priests and dignitaries of those Churches. The names mentioned have been excerpted from the published volumes of Stownik polszczyzny XVI wieku ("Dictionary of the 16thcentury Polish Language"). The article presents their origin and a consecutive history. What must be noted is quite big variety of the names of clergypersons of the denominations other than Catholic in the Polish language of the 16th century. Additionally, we can notice stability of those basic, most common designations. They are generally continued in contemporary Polish, not only in its specialist ecclesiastical variety.
\end{abstract}

Keywords: 16-th century Polish; religious lexis; clergyperson; Orthodox Church; Protestantism.

Truizmem jest stwierdzenie, że Kościół odegrał bardzo ważną rolę w dziejach naszej ojczyzny, a także w historii polskiego języka. Powstało na ten temat wiele prac, przywołam tutaj choćby nazwiska takich autorów, jak Stanisław Urbańczyk (1986), Stanisław Rospond (1985) czy Bogdan Walczak (1993; 2015).

Problematyka ta stanowi także ważną część moich badań, zwłaszcza tych dotyczących słownictwa. Zajmowałam się nazwami zakonników oraz określeniami różnorakich funkcji zakonnych i kościelnych, które potwierdzone zostały w polszczyźnie XVI wieku. Przyglądałam się ich genezie oraz dalszej historii w języku ogólnym i specjalistycznym - kościelnym czy religijnym (nie zamierzam tutaj wdawać się w dyskusję, czym jest, jeśli w ogóle jest taka odmiana, język religijny, a może kościelny?). W tym tekście chcę omówić szesnastowieczne określenia chrześcijańskich duchownych Kościołów innych niż katolicki. 
Podstawą źródłową moich rozważań jest Stownik polszczyzny XVI wieku (SPXVI 1966-2012) ${ }^{1}$. Korzystam wyłącznie z opublikowanych dotychczas tomów słownika².

Wyekscerpowane z SPXVI określenia chrześcijańskich duchownych Kościołów innych niż katolicki można podzielić na dwie grupy. Pierwszą z nich tworzą ogólne nazwy duchownych. Zaliczyć do tej grupy można 9 nazw. Są to 2 określenia duchownych prawosławnych, 6 określeń dotyczących kapłanów protestanckich i 1 nazwa ogólna. W tym miejscu chcę zaznaczyć, że w tym kontekście nie biorę pod uwagę takich ogólnych określeń odnoszących się do osób uprawnionych do pełnienia czynności związanych z kultem religijnym, jak kapłan, ksiąd, duchowny.

Prawosławnych księży w XVI wieku nazywano baćkami lub popami. Pierwsza $\mathrm{z}$ tych nazw była rzadka, pojawiła się tylko raz w wariantywnej formie $b a c$ ko. Zapisana została przez Marcina Kromera w Mnicha $z$ dworzaninem rozmowie trzeciej w 1553 roku (SPXVI 1: 288-289). O wiele częściej stosowano natomiast to określenie w polszczyźnie $\mathrm{XV}$ wieku, a najstarsza notacja pochodzi z zapisków sądów sanockich z 1448 roku (Sstp 1: 57). Nazwa (w postaci bajtko) przetrwała do XVIII stulecia (ESJPXVII/XVIII), ale współcześnie nie jest już używana, o czym świadczy jej brak w leksykograficznych opracowaniach specjalistycznych i ogólnych.

Druga nazwa prawosławnego duchownego - pop - używana była o wiele częściej. W tekstach należących do kanonu SPXVI poświadczona została 35 razy (SPXVI 27: 239). Także i ona ma tradycje średniowieczne. Potwierdzają to liczne piętnastowieczne zapisy, najstarszy z nich pochodzi z 1405 roku z przemyskiej księgi ławniczej (Sstp 6: 385-387). Forma ta przetrwała do dziś i jest popularną nazwą prawosławnego lub greckokatolickiego księdza (Gadacz, Milerski red. 8: 194; PSWP 30: 386-387; USJP 3: 361).

\footnotetext{
${ }^{1}$ Zdaję sobie sprawę, że w związku z szybkim rozwojem piśmiennictwa i literatury, w czym szczególną rolę odegrał druk i możliwość powielania tekstów w wielu egzemplarzach (Bajerowa 1980) niemożliwa była ekscerpcja wszystkich szesnastowiecznych tekstów. Powstał jednak odpowiednio skonstruowany kanon źródeł, który redakcja SPXVI charakteryzuje słowami: ,„podstawą materiałową Stownika jest zbiór tekstów XVI-wiecznych, reprezentujących możliwie wszystkie formy piśmiennicze: wierszowane i prozatorskie, ciągłe i dialogowane, retoryczne, naukowe, narracyjne itp. o różnej genezie społecznej i różnym stopniu literackości, pochodzących ze wszystkich dzielnic ówczesnej Polski” (www 1). Ponieważ autorzy SPXVI mają świadomość, że tak zebrany materiał nie będzie kompletny, uzupełniają go o „hasła nie występujące w [...] kartotece, a znalezione przygodnie $\mathrm{w}$ innych tekstach szesnastowiecznych lub $\mathrm{w}$ partiach pominiętych przy niepełnej ekscerpcji” (SPXVI 1: XXVI).

${ }^{2}$ Powtórzę to, co zaznaczam w takich sytuacjach, że bardzo trudne, jeśli nie niemożliwe są bowiem badania pozostałego materiału zgromadzonego w Pracowni SPXVI. Indeksy haseł oraz kartoteka nie są jeszcze wyposażone w znaczenia, aby więc znaleźć interesujące nazwy z nieopracowanych liter alfabetu, trzeba by przeczytać wszystkie cytaty i na ich podstawie określić znaczenia. Praca ta przekracza możliwości jednej osoby.
} 
Duchowni protestanccy nazywani byli ministrami, ministrantami, mistrzami, predykantami. Najczęściej, 121 razy, protestanckich kapłanów, pastorów, mistrzów zboru reformacyjnego określano leksemem minister (SPXVI 14: 274276). Chociaż samo słowo znane było już w poprzednim stuleciủ, nie mogło oczywiście ze względów historycznych w tekstach średniowiecznych występować $\mathrm{w}$ interesującym mnie znaczeniu. Takie znaczenie natomiast znane jest współczesnej polszczyźnie religijnej, chociaż nie jest już ono wykorzystywane (Gadacz, Milerski red. 7: 60; PSWP 21: 27).

Często, 83 razy, kaznodzieję innowierczego nazywano mistrzem (SPXVI 14: 308-321). Znaczenia tego, podobnie jak odniesienia tego określenia do duchownego katolickiego, nie znano w średniowieczu, chociaż oczywiście funkcjonował wówczas już leksem mistrz ${ }^{4}$.

Nazywając pastora, protestanckiego kaznodzieję, stosowano w szesnastym wieku także leksem predykant (SPXVI 30: 254). Trzykrotnie użył go w Przestrodze pastyrskiej w 1585 roku Stanisław Reszka. Słowo to nie było jednak idiolektalną cechą tego autora, ponieważ pojawiało się ono także w innych tekstach, o czym może świadczyć odnalezienie go w nienależącej do kanonu SPXVI Postylle krześcijańskiej części czwartej Pawła Gilowskiego z 1583 roku. Ma również w polszczyźnie kontynuację w kolejnych wiekach (ESJPXVII/XVIII), a i dzisiaj nie jest zapomnianes.

Z kolei ministrant, oznaczający protestanckiego duchownego, stanowi najprawdopodobniej określenie idiolektalne Jakuba Wujka. Leksem w tym znaczeniu poświadczony jest wyłącznie w jego tekstach - w Iudicium z 1570 roku oraz w Postylla catholica... Postylle katolicznej na niedziele części I ozimej, części II letniej z 1584 roku (SPXVI 14: 276). Skojarzenie z podstawowym, funkcjonującym zresztą do dzisiaj, znaczeniem 'usługujący księdzu przy odprawianiu mszy' może nasuwać przypuszczenie, że Wujek zastosował taką nazwę, aby zdeprecjonować protestanckiego księdza.

Możliwość ta staje się tym bardziej prawdopodobna, że często w stosunku do protestanckich duchownych stosowano takie metody. Używano ich nazw pogardliwie, ironicznie, z odcieniem złośliwości. Dotyczyło to zwłaszcza tekstów pisarzy katolickich, którzy w ten sposób zaznaczali swój negatywny stosunek do heretyków. Taką sytuację wielokrotnie zauważono w odniesieniu do nazw minister czy mistrz. Sygnalizują to nawet $\mathrm{w}$ definicjach znaczeniowych tych haseł autorzy SPXVI (SPXVI 14: 274-276, 308-321).

${ }^{3}$ Minister należał do słownictwa religijnego, oznaczał pomocnika, starszego członka bractwa tercjarskiego, pomocnika i zastępcę zakonnika opiekującego się bractwem (Sstp 4: 278).

${ }^{4} \mathrm{~W}$ średniowieczu mistrz to: 1 . 'człowiek wykształcony, uczony, nauczyciel, człowiek z tytułem naukowym magistra', 2. 'rzemieślnik o najwyższych kwalifikacjach, uprawniony do samodzielnego wykonywania swego zawodu'(Sstp 4: 287-288).

${ }^{5}$ Hasło występuje z kwalifikatorem dawny (PSWP 32: 300). 
Zwłaszcza minister wykorzystywany był jako nacechowane emocjonalnie określenie w grze słów ze złośliwym przekręceniem. Przykładowo zamiast właściwej formy minister Jan Kochanowski we Wróżkach z 1587 roku użył wyrazu minstyr, przywołując niezbyt pozytywne w kontekście funkcji kapłańskiej skojarzenie z minstrelem 'wędrownym śpiewakiem i poetą', a Stanisław Orzechowski w Rozmowie ... około egzekucujej z 1563 roku zastosował wyraz synister, nawiązując do łacińskiego przymiotnika sinister o znaczeniu 'szkodliwy, przeciwny' (SPXVI 14: 275).

Najprawdopodobniej także $\mathrm{w}$ takiej ekspresywnej funkcji pejoratywnej pojawiło się w Wizerunku fatecznego i ducha, i nauki, i pisma tych to od Lutera poczqwszy aż do dzisiejszych nowoewangelików z roku 1561 złośliwie przekształcenie ministra, kojarzące się z manija 'szaleństwem' w postaci nazwy manister (SPXVI 13: 145).

Omawiając nazwy duchownych protestanckich, trzeba też wspomnieć o rzadkich określeniach kobiet pełniących obowiązki kapłana. W polszczyźnie XVI wieku pojawiły się dwie takie nazwy: kapłanica i pastorkini. Pierwszej formy w funkcji pejoratywnej trzykrotnie użył Jakub Wujek w Iudicium (SPXVI 10: 95). Pastorkini natomiast wystąpiła w Księgach o jasnym a szczyrym Słowie Bożym Stanisława Hozjusza z roku 1562 roku (SPXVI 23: 293). W tym miejscu warto zauważyć, że nieznany jest szesnastowiecznemu językowi leksem pastor $^{6}$.

Ogólną nazwą osoby uprawnionej do pełnienia czynności związanych z kultem religijnym jest natomiast pasterz. Szesnastowieczne teksty potwierdzają użycie tego leksemu na oznaczenie duchownego chrześcijańskiego aż 502 razy. Jak wynika $\mathrm{z}$ informacji SPXVI, często określano w ten sposób zwłaszcza kościelnego dostojnika, kapłana wysokiego rangą (SPXVI 23: 287-290), ale pasterzem można było także nazwać duchownych różnowierczych, nie tylko katolickich czy w ogóle chrześcijańskich. W takim znaczeniu użyta została ta nazwa w Biblii brzeskiej z 1563 roku, zastosowali ją Marcin Kromer w Mnicha z dworzaninem rozmowie trzeciej w 1553 roku, Stanisław Orzechowski w Listach w 1561 roku, Jakub Wujek w Konfessyji w 1570 roku, Szymon Budny w przedmowie do Nowego Testamentu w 1574 roku, Marcin Czechowic w Epistomium w 1583 roku. Słowo to ma proweniencję średniowieczną, najstarszy zapis pochodzi z Kazań gnieźnieńskich (Sstp 6: 46). Stosowano je często, jednak nie oznaczało ono wówczas kapłana, odnosiło się wyłącznie do tego, kto pilnował pasącego się bydła, owiec, świń. Mogło też nazywać Chrystusa jako Dobrego Pasterza. Współcześnie terminologia kościelna, czy szerzej religijna, kontynuuje wspominane znaczenia szesnastowieczne, stosując wspomniany leksem w sytuacjach oficjalnych, podniosłych (PSWP 28: 357-358; USJP 3: 66).

${ }^{6}$ W tym miejscu warto zauważyć, że omówione wyżej, funkcjonujące w szesnastowiecznej polszczyźnie określenia duchownych innych niż katolickie religii chrześcijańskich, mogły także być wykorzystane do nazwania księży pozostałych wyznań, głównie kapłanów katolickich. Kwestie te omawiam w innym artykule (Migdał w druku). 
Do drugiej grupy określeń chrześcijańskich duchownych Kościołów innych niż katolicki zaliczyć z kolei należy nazwy księży wyższych rangą, dostojników tych Kościołów. SPXVI odnotował 12 takich leksemów. Większość z nich odnosi się do kapłanów Kościoła wschodniego, prawosławnego ${ }^{7}$. Czasem nazwy te są wspólne dla duchownych Kościoła katolickiego oraz Kościoła prawosławnego, co zaznaczają autorzy SPXVI. Przykładem mogą być określenia metropolit i metropolitan. Pierwsza z nich, częstsza - zapisano ją 40 razy, mogła wystąpić $\mathrm{w}$ różnych wariantywnych formach: metropolit, metropolita, mitropolit, metrapolit lub metropolita (SPXVI 13: 285). Oznaczała arcybiskupa, który stał na czele prowincji kościelnej, obejmującej kilka diecezji. Używali jej: Andrzej Glaber w thumaczeniu Polskiego wypisania dwojej krainy świata Macieja Miechowity w 1535 roku, Marcin Kromer w Mnicha z dworzaninem rozmowie trzeciej w 1553 roku, Stanisław Orzechowski w Rozmowie ... około egzekucujej w 1563 roku, Marcin Bielski w Kronice w 1564 roku, Jakub Wujek w Iudicium w 1570 roku, Szymon Budny w Nowym Testamencie w 1574 roku, Piotr Skarga w O jedności Kościoła bożego w 1577 roku, Maciej Stryjkowski w Kronice polskiej w 1582 roku. Druga z tych nazw - metropolitan - wystąpiła w tym samym znaczeniu siedmiokrotnie w słowniku Jana Mączyńskiego z 1564 roku, u Marcina Krowickiego w Obronie nauki z 1560 roku, Marcina Bielskiego w Kronice z 1564 roku, Jakuba Wujka w Iudicium z 1570 roku, Jana Niemojewskiego w Obronie przeciw niesprawiedliwemu obwinieniu z 1583 roku oraz Stanisława Sarnickiego w Statutach i metryce przywilejow koronnych z 1594 roku (SPXVI 13: 285-286). Tradycję średniowieczną ma tylko forma metropolit (mitropolit), która - zanotowana w 1458 roku w dyplomariuszu lwowskim oraz także w zapiskach sądów halickich - odnosiła się właśnie do biskupa w Kościele obrządku wschodniego (Sstp 4: 182). We współczesnej polszczyźnie funkcjonuje nadal forma metropolita jako określenie arcybiskupa stojącego na czele metropolii, czyli kościelnej prowincji składającej się z kilku diecezji (Gadacz, Milerski, red. 6: 510; EK 12: 666; PSWP 21: 53; USJP 2: 618).

Przez swoiste przeniesienie nazwy także inne leksemy odnoszą się nie tylko do dostojników Kościoła katolickiego. Są to takie nominacje, jak papież czy patryjarcha.

W stosunku do najwyższego zwierzchnika Kościoła rzymskokatolickiego w XVI wieku używano różnych określeń, ale najczęściej stosowaną nazwą był właśnie papież, który w tekstach kanonu źródeł SPXVI wystąpił aż 3456 razy (SPXVI 23: 235-239). Taki sposób nazywania biskupa rzymskiego, będącego głową Kościoła katolickiego, w języku polskim znany był już w okresie średniowiecza, a najstarsze zapisy pochodzą z początków XV stulecia: z Kazań gnieźnieńskich i z roku 1424 z Kanonu Mszy świętej (Sstp 6: 36). W XVI wieku jednak czterokrotnie nazwano papieżem zwierzchnika Kościołów wschodnich. W takiej

${ }^{7}$ W taki sposób określają to leksykografowie SPXVI. 
funkcji użyli tej nazwy Marcin Krowicki w Obronie nauki prawdziwej w 1560 roku i Marcin Bielski w Kronice w 1564 roku. Określenie to zostało też jeden raz zastosowane w tłumaczeniu Andrzeja Glabera dzieła Macieja Miechowity Polskie wypisanie dwojej krainy świata z 1535 roku na określenie zwierzchnika Kościoła ormiańskiego.

Z kolei leksem patryjarcha w XVI stuleciu mógł występować jeszcze w kilku znaczeniach odnoszących się do kręgu biskupiego. Pojawiał się jako miano papieża lub prymasa, ale przede wszystkim używany był w celu nazwania biskupa mającego siedzibę w jakimś $\mathrm{z}$ najstarszych ośrodków chrześcijaństwa. W takiej funkcji odnosił się także do zwierzchników Kościoła Wschodniego po schizmie (SPXVI 23: 318-319).

Patriarcha Kościoła grecko-wschodniego mógł używać tytułu podkreślającego jego rangę i charakter - ekumenikus. Leksem ten przywoływał powszechność, uniwersalność, co odnosiło się do cech Kościoła. Powszechność Kościoła (w myśl nicejsko-konstantynopolitańskiego wyznania wiary) należy do czterech jego znamion (obok jedności, świętości i apostolskości) i oznacza, iż jest on powołany do działania wśród całej ludzkości, obejmując swą działalnością wszystkich ludzi, niezależnie od ich płci, stanu, majątku, narodowości czy popełnionych grzechów. Tytuł ten w szesnastowiecznej polszczyźnie odnotowany został wyłącznie w tekstach Piotra Skargi (SPXVI 6: 543-544).

Kolejnym szesnastowiecznym określeniem kościelnego przełożonego, biskupa, zwłaszcza w Kościele wschodnim była nazwa episkop (także w formie episkopus) (SPXVI 6: 557). Wystąpiła ona pięciokrotnie u Marcina Kromera w Mnicha $z$ dworzaninem rozmowie trzeciej w 1553 roku, Szymona Budnego w Nowym Testamencie w 1574 roku oraz w dziele Andrzeja Frycza Modrzewskiego - Cypriana Bazylika O poprawie Rzeczypospolitej w 1577 roku. Forma ta nie jest w polszczyźnie kontynuowana.

Według danych SPXVI odpowiedni tytuł - prototron - przysługiwał 'biskupowi diecezji włodzimierskiej w Kościele Wschodnim’ (SPXVI 30: 459). Potwierdzony on został wyłącznie w źródłach spoza kanonu: u Marcina Broniewskiego w Apokrisis abo odpowiedzi na ksiązki o synodzie brzeskim z około 1597 roku i u Piotra Skargi w Synodzie brzeskim z 1597 roku. Leksem ten nie ma kontynuacji w późniejszej polszczyźnie.

Do dostojników Kościoła wschodniego zaliczyć też trzeba protopopa i prymikiryja. Protopop był starszym popem, przełożonym kleru katedralnego w kościele wschodnim. Pisał o nim Maciej Stryjkowski w Kronice polskiej w 1582 roku, leksem ten znalazł też potwierdzenie w źródłach spoza kanonu: w Konstytucjach... z 1581 roku, w Uniwersale poborowym z 1581 roku oraz w Ekthesis abo Krótkim zebraniu spraw... z 1597 roku (SPXVI 30: 459). Warto zauważyć, że we wszystkich tekstach występował zawsze z nazwą miejscową lub przymiotnikiem od niej. Nazwa ta na pewno była znana jeszcze w XVII wieku, o czym świadczą cytaty 
zamieszczone w Słowniku języka polskiego Samuela Bogumiła Lindego (Linde 4: 1051). Współcześnie nie jest używana, chociaż ogólne słowniki języka polskiego odnotowują ją, odsyłając do hasła protojerej (PSWP 33: 41-42, 46).

Z kolei prymikiryj oznaczał dostojnika pełniącego wysoką funkcję związaną z synodem prawosławnym (SPXVI 30: 506). Nazwę tę wyekscerpowano ze źródła spoza kanonu, poświadczona została w Ekthesis abo Krótkim zebraniu spraw... z 1597 roku. W języku polskim nie ma ona kontynuacji. Encyklopedia katolicka zamieszcza hasło prymikiriusz i prymiceriusz, informując, że nazwy te stanowią tytuł wyższego urzędnika administracji cesarskiej oraz kościelnej (EK 16: 595).

Kolejną nazwą odnoszącą się do dostojnika kościelnego innego niż katolicki Kościoła jest określenie protosyngiel (SPXVI 30: 459). W ten sposób określano wikariusza patriarchy Kościoła greckiego, przełożonego duchownych z jego otoczenia. Znamy ją wyłącznie z tekstów spoza kanonu źródeł SPXVI: z Apokrisis abo odpowiedzi na książki o synodzie brzeskim z około 1597 roku Marcina Broniewskiego, Ekthesis abo Krótkiego zebrania spraw... z 1597 roku oraz Antirresis abo apologii przeciwko Krzysztofowi Filaletowi z 1600 roku. Według autorów Encyklopedii katolickiej współcześnie funkcjonują dwie formy tej nazwy: protosynkellos i protosyncellus, które oznaczają 'w prawie Kościołów wschodnich najbliższego współpracownika biskupa eparchialnego i egzarchy’ (EK 16: 534-535). W Kościele łacińskim odpowiada tej funkcji wikariusz.

Ze źródła spoza kanonu SPXVI wyekscerpowano jeszcze jedno określenie, prawdopodobnie dotyczące wysokiego rangą duchownego Kościoła innego niż katolicki. Akta synodów różnowierczych w Polsce z roku 1583 zawierają nazwę rektor, w połączeniu rektor synodu, odnoszącą się do 'przewodniczącego synodu innowierczego' (SPXVI 35: 199-200). Takie znaczenie współcześnie nie jest w polszczyźnie kontynuowane.

Ostatnia interesująca mnie w kontekście podjętego tematu szesnastowiecznych określeń duchownych innych wyznań nazwa to abunan (SPXVI 1: 45). Leksem ten stanowi tytuł głowy Kościoła etiopskiego i poświadczony został w Kronice Marcina Bielskiego w 1564 roku. Określenie to przetrwało do dzisiaj w zmodyfikowanej postaci abuna, abune, w tym samym co szesnastowieczne znaczeniu (Gadacz, Milerski red. 1: 38).

Podsumowując, powtórzę to, co już wielokrotnie podkreślałam w zakończeniach moich wystąpień dotyczących szesnastowiecznej leksyki religijnej. Trzeba zauważyć dość dużą różnorodność nazw osób duchownych innych niż katolickie wyznań w języku XVI wieku. Widoczna jest też duża stabilność tych podstawowych, najbardziej powszechnych określeń, na ogół kontynuowane są one i we współczesnej polszczyźnie, i nie tylko w jej specjalistycznej kościelnej odmianie. Silna jest tradycja polskiej nomenklatury kościelnej. 


\section{BIBLIOGRAFIA}

(www 1) www.ibl.waw.pl [dostęp: 20.11.2015].

Bajerowa I., 1980, Wpływ techniki na ewolucję języka polskiego, Kraków.

EK - Encyklopedia katolicka, 1973-2014, t. 1-20, Lublin.

ESJPXVII/XVIII - Elektroniczny stownik języka polskiego XVII i XVIII wieku, www. sxvii.pl [dostęp: 20.11.2015].

Gadacz T., Milerski B. (red.), 2001-2003, Religia. Encyklopedia PWN, t. 1-9, Warszawa.

Linde - Linde S.B., 1807-1814, Słownik języka polskiego, t. 1-6, Warszawa.

Migdał J., w druku, Określenia duchowieństwa w polszczyźnie XVI wieku.

PSWP - Zgółkowa H. (red.), 1994-2005, Praktyczny słownik współczesnej polszczyzny, t. 1-50, Poznań.

Rospond S., 1985, Kościół w dziejach języka polskiego, Wrocław.

SPXVI - Mayenowa M.R., Pepłowski F., Mrowcewicz K. (red.), 1966-2012, Słownik polszczyzny XVI wieku, t. 1-36, Wrocław-Warszawa-Kraków-Gdańsk.

Sstp - Urbańczyk S. (red.), 1953-2002, Stownik staropolski, t. 1-11, Kraków.

Urbańczyk S., 1986, Jak pojmować rolę Kościoła $w$ dziejach języka polskiego, „Język Polski", z. 3-4, s. 170-175.

USJP - Dubisz S. (red.), 2003, Uniwersalny słownik języka polskiego, t. 1-4, Warszawa.

Walczak B., 1993, Komu zawdzięczamy polski język literacki?, w: Język a chrześcijaństwo, red. I. Bajerowa, M. Karpluk, Z. Leszczyński, Lublin, s. 23-42.

Walczak B., 2015, Religijno-kościelny czynnik sprawczy rozwoju języka polskiego, w: Język. Religia. Tożsamość XI: Język tożsamości, red. G. Cyran, E. Skorupska-Raczyńska, Gorzów Wielkopolski, s. 185-200. 